\title{
Nexuses between Economic Factors and Stock Returns in China
}

\author{
Muhammad Kamran Khan ${ }^{1}$, Jian-Zhou Teng ${ }^{1}$, Javed Pervaiz ${ }^{1} \&$ Sunil Kumar Chaudhary ${ }^{1}$ \\ ${ }^{1}$ School of Economics, Northeast Normal University, Changchun Jilin, China \\ Correspondence: Jian-Zhou Teng, School of Economics, Northeast Normal University, Renmin Street Number \\ 5268, Changchun 130024, China. Tel: 86-135-9618-5588. E-mail: tengjz270@ nenu.edu.cn
}

Received: August 4, 2017

Accepted: August 21, 2017

Online Published: August 25, 2017

doi:10.5539/ijef.v9n9p182

URL: https://doi.org/10.5539/ijef.v9n9p182

\begin{abstract}
Economist and stock managers always focus on stock market return. This study investigated short and long run relationship between economic factors and stock returns in China by applying ARDL approach from 01/2000 to 12/2016. Estimated results of bound test for co-integration shows that long run relationships exist among the variables except inflation rate. Results of short and long run ARDL demonstrate that exchange rate and inflation rate have positive effect on stock returns in China while interest rate have negative effect on stock returns. Results indicate that stock returns in China are very sensitive and can be affected positively or negatively with increase and decrease in economic factors. Both local and regional factors in China can directly and indirectly explain Shanghai Stock Exchange stock returns.
\end{abstract}

Keywords: stock returns, economic factors, ARDL

\section{Introduction}

Economic theory suggests that stock prices should reflect investor's expectations about the future firm profits. In that sense, profits reflect the level of aggregate economic activity. Economic theory implies that there should be two way causal relationships between economic activity and stock market prices. Economic variables have a significant impact on stock market performance and reversely, stock markets have a significant role on the economic growth. As it will be listed below, many previous studies have reported the effects of macroeconomic variables on stock prices in different countries.

Stock market behavior can be explained by the dynamic interaction among various macroeconomic variables, such as inflation rate, interest rate, and exchange rate. This paper aims to investigate short and long run causal association among key economic factors, including Inflation (CPI), Interest rate, Exchange rate and the stock market return of Shanghai Stock Exchange Composite Index in China, represented by the 000001.SS.

In the study, monthly data is used from 2000:1 to 2016:12, which is different from previous studies, the ARDL methodology is used for estimations. By taking 000001.SS stock market return of Shanghai Stock Exchange as dependent variable and Inflation rate, Interest rate and Exchange rate as independent variables for considering the short and long run effects of these variables on stock returns.

In the study, benefiting from economic literature in general and the literature about the China economic developments, key economic elements are Inflation rate, Interest rate and Exchange rate. In order to represent economic activity in China, monthly data of Inflation rate, Interest rate and Exchange rate are used to see their effect on stock returns.

Economic theory indicates that stock prices should represent investors' objectives about the future firm profits. For the reason that sense, profits reflect the level of aggregate economical activities. On theoretical grounds, the positive association between stock prices and economical factor is expected. This expectation is also reinforced by empirical studies of Chen et al. (1986), Fama (1990). Gallinger (1994) noted that asymmetric causation runs from stock returns to real economic activity. The stock returns economic activity causal relationship can be reviewed as follows. First of all, there's a link from the consequences of major economic factors on stock return fluctuations.

Another economic factor that has influence on stock prices is the changes in the purchase price level. The association between price level changes and stock prices are represented by changes in Inflation (Consumer Price Index). The CPI focuses on the price of goods and services traded among the firms. It also displays price 
moves that reflect supply and demand in the real current economy. Theoretically it is expected a negative or positive association between price level changes and stock prices/dividends. Two situations can clarify these negative associations. First, according to the classical theory implications and Fama (1981), such relationships are induced by the negative inflation-real activity association and so, stock returns are positively related to real variables like investment expenses and output. Second, increased inflation may improve the nominal risk-free rate and thus the discount rate. The positive association, on the other hand, is suggested by the Keynesian approach since there exists positive relationship are present between economic activity and price level and therefore there must be a positive association between activity and the stock returns. Bornholt (2013) expanded on the popular CAPM and developed an equilibrium asset pricing model in which positive inflation rate and low earnings systems are connected with increase in overall stock return. The two studies by Dempsey (2013) and Bornholt (2013) demonstrated the inconclusiveness of different study outcomes and methodologies on the nexus between stock returns and economic fundamentals.

Another variable which is included in this study is the exchange rate. Theoretically, change in exchange rate affects the global performances of the firms which will affect their share prices. Abdalla and Murinde, (1997) and Choi (1995) stated that exchange rate have positive effect on stock returns.

Changes in interest levels affect the cost of borrowing and also effects future profitability of the organizations. For instance, a fall season in interest levels reduces the cost of borrowing and motivates firms for development with the expectation of making future expected results for the organization. Interest rate changes play an important role in stock price activities. Theoretically, it is expected that an increase in interest rates or interest difference between Chinese interest rate policies have a negative effect on stock returns, since an increase in rates of interest may raise financing costs, and then reduce future commercial success and stock prices. However, opposite to targets, Mukherjee and Naka (1995) found a positive connection between Japanese stock prices and exchange rates.

The Shanghai Stock Exchange Composite Index is recognized as the best agent of the China equities market. The Shanghai Stock Exchange Composite Index is a capitalization-weighted index. The index monitors the daily price performance of all A-shares and B-shares outlined on the Shanghai Stock Exchange. The index was developed on December 19, 1990 with basics value of 100. Index trade level on Q is scaled down by one factor of 1000. Theoretically, a positive relationship is expected between different economic factors and Shanghai stock returns.

\section{Literature Review}

Khalid (201) conducted investigation among macroeconomic elements and stock return using time series data in Pakistan. He applied correlation and Co-integration model to examine Co-integration association among macroeconomic elements and stock return. He pointed out non positive significant association between stock return and independent variables, estimated statistical results stated that most of the changes ensue in stock returns due to variation in Inflation a little change accrue due to other variables.

Kwon and Shin (1999) studied association between macroeconomic elements and stock returns in Korea. Co-integration results pointed out that economic variables cannot affect stock return; results are not same with the theoretical implications and earlier research pointed out that the stock market rationally signals changes in real activities.

Şükrüoğlu and Nalin (2014) investigate 19 European countries stock market and pointed out macroeconomic elements that influence on stock market. Authors pointed out negative effect of monetization ratio and inflation on stock market development while pointed out positive effect of income, liquidity ratio, saving rate stock market development. They stated that stock market can be development with liquid assets.

Sahu and Dhiman (2011) examined relationship among economic development and stock market growth and the direction of causality in India from 1981 to 2006. They pointed out causal relationship among dependent and independent variables.

Singh and Mehta (2011) conduct study on Taiwan stock return and macroeconomic elements. They used GDP, inflation, exchange rate, employment and growth rate of money as independent and stock return was taken as dependent variable. Regression, mean, variance, and the Kolmogorov D-statistic normality test were used as model. They used 50 Taiwan companies' data, they revealed that GDP and exchange rate effects all portfolios returns, while pointed out negative impact on stock returns of big corporations.

Husam and Turgut (2009) investigated correlation between Istanbul stock exchange and macroeconomic elements. They applied APT model, CAPM, Correlation and Regression models for association between stock 
return and economic elements. They pointed out that stock return have significant association with inflation. Unanticipated inflation, money supply, risk premium and term structure of interest rate have significant impact on various portfolios of stock return. On the base of findings these results have week expounding power.

Kuwornu (2012) studied the macroeconomic element's effect on stock return by applying co-integration model. He used Co-integration model to inspect relation between macroeconomic variables and stock return. He perused that, In Ghana stock return is affected from inflation in short and in long run. In short run investor cannot reimburse from inflation but in long run can be compensated.

Kanas and Karkalakos (2017) explored the effects of equity flows between U.S. and U.K. investors upon equity and exchange rate returns within a unified empirical framework on the basis of a trivariate vector autoregressive system that incorporates mean and volatility spillovers and allows for dynamic conditional correlations. They pointed out that volatility spillovers across equity returns, exchange rate returns, and equity flows. They found strong evidence that U.K. investors rebalance their portfolios by engaging in a positive feedback trading known in the literature as "trend chasing." They documented strong dynamic effects from net flows to equity returns, illustrating a trading rule that portfolios are dynamically adjusted over a short - run horizon influencing changes in stock returns.

Alagidede and Panagiotidis (2010) applied co-integration tests and further estimate vector error correction models (VECM's) for 6 African stock exchanges, namely, the JSE, the Egyptian Exchange (EGX), the Nigerian Stock Exchange (NSE), the Nairobi Stock Exchange (NSE-Kenya) and Tunis Stock Exchange (BVMT). The authors find that time path of the response of stock prices to a shock in inflation produces an initial negative short-run response for equities in both the JSE and the EGX, whereas this effect eventually turns positive over the long-run. Conversely, for the NSE, the NSE-Kenya and the BVMT, the stocks returns react to innovations.

Arjoon et. al. (2011) estimates a bi-variate structural vector autoregressive (SVAR) of inflation and stock returns for South Africa using quarterly data collected from 1980:Q1 to 2010:Q2. By using three identification schemes on the structure of the SVAR model, the authors pointed out positively response of real stock prices with permanent shock in inflation rate with short-term deviations of real stock prices from their steady state equilibrium been eventually corrected over the long-run.

Eita (2012) uses conventional granger causality analysis and error correction modeling to investigate the inflation-stock returns relationship for South African quarterly data collected from 1980:Q1 to 2008:Q4. The author uses two proxies to measure stock returns namely i) the all-share index (ALSI), and ii) the gold index. Regardless of which proxy of stock returns is used, the empirical results pointed out positively relationship of inflation with stock returns, even though causality is found to be bi-directional between ALSI and inflation, whilst causality is unidirectional from inflation to the gold index.

Khumalo (2013) used ARDL and VECM models to point out the consequences of inflation on stock prices applying quarterly South African collected from 1980:Q1 to 2010:Q4. Significant negative cointegration effects between inflation and stock prices are found with causality established to run unidirectional from inflation to stock prices with an unexpected increase in the inflation rates causing a negative response on stock prices in the long-run.

Tripathi and Kumar (2014) inspected relationship between inflation and stock returns for BRICS countries using monthly data collected from 2000:01 to 2013:09. By using bi-variate correlation analysis and granger causality tests the authors stated that inflation positively affect stock returns in Brazil and China, a significant negatively effect in South Africans countries and no significant relationship in China and Russia. Furthermore, the causality tests point to no causality between the variables for Brazilian data

Marx and Struweg (2015), the authors investigate the effects of stagflation on equity price for the JSE from 1969 to 2013. In the empirical study, stagflation is defined as an economic environment where inflation rates above the upper band of the inflation target (i.e. 6 percent) and GDP is below its potential growth level and thereafter the authors apply multiple regression/correlation (MRC) analysis and provide regressions estimated for stagflation and no-stagflation. During stagflation, empirical results reveal that inflation have negative significant effect on stock market returns, whereas this association remains negative but becomes less insignificant during periods of no stagflation.

Menike (2006) investigated macroeconomic element's effect on Stock Prices in emerging evidence stock exchange in Seri Lanka. He used Single and multifactor models, regression and coefficient models. Inflation, exchange rate, interest rate and money supply were taken as independent variables and stock return was taken as dependent variable. He pointed out that inflation have negative but significant effect on stock return in Seri 
Lanka. He found that, Inflation cannot be hedged in diversified, trending and manufacturing sectors. Inflation and stock prices negatively but exchange rate positively affect the stock market.

\section{Method}

We utilize monthly data in the present study ranging from January 2000 to December 2016. The monthly data for China's Inflation rate (We used CPI as a proxy for measuring inflation rate), Interest rate and exchange rate are taken from the Federal Reserve Economic Data and Stock return data from Shanghai Stock Exchange Composite Index represented by the 000001.SS.

$$
S T R_{t}=\beta_{0}+\beta_{1} I N F_{t}+\beta_{2} I N T_{t}+\beta_{3} E X C R_{t}+\varepsilon_{t}
$$

Where

STR is Stock return of Shanghai Stock Exchange;

INF is Inflation rate;

INT is Interest rate;

EXCR is Exchange rate;

$\varepsilon$ is the error term;

$\mathrm{t}$ is time from $2000 / 01$ to $2016 / 12$.

\subsection{Auto Regressive Distributed Lag (ARDL) Approach}

Autoregressive distributed lag (ARDL) approach is applied in this study which was developed by Pesaran and Shin (1999) and re-assessed by Pesaran et al. (2001). We used ARDL to analyze the short and long run linkages between selected economic variables and the stock returns in China. The ARDL approach provides several advantages over traditional methods for evaluate of co-integration and short-run and long-run linkages. Firstly, opposite to traditional co-integration methods such as Johansen's tests (Johansen, 1991), Granger and Engle causality test (Engle \& Granger, 1987) and Vector Autoregressive (VAR) model, the ARDL can be utilized to test for a level relationship for variables that are either at level or first difference as well as for mix I(0) and I(1) variables (Duasa, 2007; Adom et al., 2012). But ARDL approach does not apply with non-stationary variables integrated of order two $\mathrm{I}(2)$. The possibility to combine $\mathrm{I}(0)$ or $\mathrm{I}(1)$ variables is great advantage as financial time series often are either at stationary at level or first difference. The advantage can be more clarified by comparing e.g. VAR with ARDL. If one would conduct a VAR approach the series are required to be stationary and if the data is non-stationary I(1) one would have to take the first difference of the series and then apply VAR. However if one take the first difference of the data, long-run relations between series may disappear (Brooks, 2014). In contrast, in an ARDL framework it is not necessary to make an adjustment to the data and hence long-run relationships still remain possible to calculate. Secondly, the ARDL method integrates the short-run impact of the given variables with a long-run equilibrium using an error correction term without dropping long-run information. Accordingly one may assess the short-run and long-run relationship between the given variables simultaneously. Thirdly, unlike traditional cointegration tests, it is possible to determine different lags for each variable in the model which makes it more flexible. Lastly, most co-integration techniques are sensitive to the sample sizes while the ARDL method provides robust and consistent results for small sample sizes (Adom et al., 2012). In order to investigate the causal relationship between selected economic variables and stock returns in China, the ARDL approach is used, which is defined as follows in equations:

$$
\begin{gathered}
\Delta S T R_{t}=\beta_{0}+\sum_{t-1}^{W} \beta_{1} i \Delta S T R_{t-1}+\sum_{t-1}^{W} \beta_{2} i \Delta I N F_{t-1}+\sum_{t-1}^{W} \beta_{3} i \Delta I N T_{t-1}+\sum_{t-1}^{W} \beta_{4} i \Delta E X C R_{t-1}+\beta_{5} S T R_{t-1}+\beta_{6} I N F_{t-1}+ \\
\beta_{7} I N T_{t-1}+\beta_{8} E X C R_{t-1}+\varepsilon_{t} \\
\Delta I N F_{t}=\beta_{0}+\sum_{t-1}^{W} \beta_{1} i \Delta I N F_{t-1}+\sum_{t-1}^{W} \beta_{2} i \Delta S T R_{t-1}+\sum_{t-1}^{W} \beta_{3} i \Delta I N T_{t-1}+\sum_{t-1}^{W} \beta_{4} i \Delta E X C R_{t-1}+\beta_{5} I N F_{t-1}+\beta_{6} S T R_{t-1}+ \\
\beta_{7} I N T_{t-1}+\beta_{8} E X C R_{t-1}+\varepsilon_{t} \\
\Delta I N T_{t}=\beta_{0}+\sum_{t-1}^{W} \beta_{1} i \Delta I N T_{t-1}+\sum_{t-1}^{W} \beta_{2} i \Delta I N F_{t-1}+\sum_{t-1}^{W} \beta_{3} i \Delta S T R_{t-1}+\sum_{t-1}^{W} \beta_{4} i \Delta E X C R_{t-1}+\beta_{5} I N T_{t-1}+\beta_{6} I N F_{t-1}+ \\
\beta_{7} S T R_{t-1}+\beta_{8} E X C R_{t-1}+\varepsilon_{t} \\
\Delta E X C R_{t}=\beta_{0}+\sum_{t-1}^{W} \beta_{1} i \Delta E X C R_{t-1}+\sum_{t-1}^{W} \beta_{2} i \Delta I N T_{t-1}+\sum_{t-1}^{W} \beta_{3} i \Delta I N F_{t-1}+\sum_{t-1}^{W} \beta_{4} i \Delta S T R_{t-1}+\beta_{5} E X C R_{t-1}+ \\
\beta_{6} I N T_{t-1}+\beta_{7} I N F_{t-1}+\beta_{8} S T R_{t-1}+\varepsilon_{t}
\end{gathered}
$$

In equations ( 2 to 5 ), $\Delta$ is the first difference operator, $\beta_{0}$ is constant, $\varepsilon_{t}$ is white noise error term, the first part of the equations with parameter $\beta_{1}$ to $\beta_{4}$ represents the error correction dynamics and the second part from $\beta_{5}$ to $\beta_{8}$ represents the long-run relationship of the model. To examine the existence of the long-run relationship between the dependent variable STR and its determinants, an $F$-test procedure is followed for the joint 
significance of the coefficients of the lagged levels of the variables, $\left\{H_{0}: \beta_{1}=\beta_{2}=\beta_{3}=\beta_{4}=0\right\}$ against $\left\{H_{1}: \beta_{1} \neq \beta_{2} \neq \beta_{3} \neq \beta_{4} \neq 0\right\}$. The non-rejection of the null hypothesis indicates the existence of a long-run relationship or cointegration. Pesaran et al. (2001) propose lower and upper critical values for the F-statistic assuming all variables are $\mathrm{I}(0)$ for the lower bound and all variables are $\mathrm{I}(1)$ for the upper bound. If the computed F-statistic exceeds the upper critical value, then there is evidence of cointegration relationships between the variables irrespective of the order of integration of the variables. Conversely, if the test statistic falls below the lower critical bound, then the null of no cointegration cannot be rejected. However, if the test statistic falls between the lower and upper critical values, then the result is inconclusive. The short-run dynamics are then estimated through the error correction model as follow.

$$
\begin{aligned}
\Delta S T R_{t} & =\beta_{0}+\sum_{t-1}^{W} \beta_{1} i \Delta S T R_{t-1}+\sum_{t-1}^{W} \beta_{2} i \Delta I N F_{t-1}+\sum_{t-1}^{W} \beta_{3} i \Delta I N T_{t-1}+\sum_{t-1}^{W} \beta_{4} i \Delta E X C R_{t-1}+\eta_{1} E C T_{t-1}+\varepsilon_{t} \\
\Delta I N F_{t} & =\beta_{0}+\sum_{t-1}^{W} \beta_{1} i \Delta I N F_{t-1}+\sum_{t-1}^{W} \beta_{2} i \Delta S T R_{t-1}+\sum_{t-1}^{W} \beta_{3} i \Delta I N T_{t-1}+\sum_{t-1}^{W} \beta_{4} i \Delta E X C R_{t-1}+\eta_{2} E C T_{t-1}+\varepsilon_{t} \\
\Delta I N T_{t} & =\beta_{0}+\sum_{t-1}^{W} \beta_{1} i \Delta I N T_{t-1}+\sum_{t-1}^{W} \beta_{2} i \Delta I N F_{t-1}+\sum_{t-1}^{W} \beta_{3} i \Delta S T R_{t-1}+\sum_{t-1}^{W} \beta_{4} i \Delta E X C R_{t-1}+\eta_{3} E C T_{t-1}+\varepsilon_{t} \\
\Delta E X C R_{t} & =\beta_{0}+\sum_{t-1}^{W} \beta_{1} i \Delta E X C R_{t-1}+\sum_{t-1}^{W} \beta_{2} i \Delta I N T_{t-1}+\sum_{t-1}^{W} \beta_{3} i \Delta I N F_{t-1}+\sum_{t-1}^{W} \beta_{4} i \Delta S T R_{t-1}+\eta_{4} E C T_{t-1}+\varepsilon_{t}
\end{aligned}
$$

In the above equations from (6 to 9) $E C T_{t-1}$ is the error correction term obtained from the cointegration model. The error coefficients $\left(\eta_{1}, \eta_{2}, \eta_{3}, \eta_{4}\right)$ indicate the rate at which the cointegration model corrects its previous period's disequilibrium or speed of adjustment to restore the long run equilibrium relationship. A negative and significant $E C T_{t-1}$ coefficient implies that any short run movement between the dependent and explanatory variables will converge back to the long run relationship.

\subsection{Stability, Diagnostic and Stationarity}

Presence of serial correlation and Heteroskedasticity in the errors of model is tested and whether it is correctly specified the functional form of the model and errors are normally distributed. Also, it is checked the stability of parameters by using cumulative (CUSUM) and cumulative sum of squares (CUSUMSQ) suggested by Brown et al. (1975). In regression analysis of time series, the properties of data are crucial and need much scrutiny. Generally, they contain a unit root and tend to be non-stationary. Gujarati and Porter (2009) argued that to avoid any inconsistencies in coefficient estimation, series are required to be stationary. Therefore, it is critical to check the stationarity properties and to identify the integration order of each series. The Standard Augmented

\begin{tabular}{|c|c|c|c|c|}
\hline \multicolumn{3}{|c|}{ Augmented Dickey-Fuller } & \multicolumn{2}{|c|}{ Phillips-Perron } \\
\hline \multicolumn{5}{|c|}{ Level } \\
\hline Variables & Intercept & Trend \& Intercept & Intercept & Trend \& Intercept \\
\hline STR & $-12.4659(0.0000)$ & $-12.4376(0.0000)$ & $-12.8944(0.0000)$ & $-12.8667(0.0000)$ \\
\hline INF & $0.0106(0.9576)$ & $-3.8373(0.0166)$ & $0.6023(0.9895)$ & $-3.0337(0.1257)$ \\
\hline INT & $-2.5637(0.1037)$ & $-2.5549(0.3016)$ & $-2.8828(0.0491)$ & $-2.8783(0.1718)$ \\
\hline EXCR & $-1.1450(0.6978)$ & $0.7180(0.9997)$ & $-1.0868(0.7211)$ & $0.3764(0.9989)$ \\
\hline \multicolumn{5}{|c|}{ First Difference } \\
\hline STR & $-15.2491(0.0000)$ & $-14.2174(0.0000)$ & $-50.0548(0.0001)$ & $-49.9369(0.0001)$ \\
\hline INF & $-12.8656(0.0000)$ & $-12.8269(0.0000)$ & $-11.2370(0.0000)$ & $-11.2818(0.0000)$ \\
\hline INT & $-12.7952(0.0000)$ & $-12.7644(0.0000)$ & $-12.7952(0.0000)$ & $-12.7743(0.0000)$ \\
\hline EXCR & $-7.2738(0.0000)$ & $-7.4363(0.0000)$ & $-7.2220(0.0000)$ & $-7.3907(0.0000)$ \\
\hline
\end{tabular}
Dickey-Fuller (ADF) and Philip Pesaran (PP) unit-root tests are used for potential non-stationary concerns.

\section{Empirical Results and Discussions}

Table 1. Unit root test results

As a first step, the likely non-stationary concern was addressed using a Standard Augmented Dickey-Fuller (ADF) and Philip Pesaran (PP) test. Even though the Autoregressive Distributed-lag (ARDL) technique does not necessitate prior checking of the unit root issue, in the empirical analysis it is essential to undertake this test to ascertain that variables do not have a unit root problem and their integration order is not more than one. Table 1 reports the ADF and PP unit-root test result. The ADF and PP unit-root test were applied on two sets, being intercept and intercept with time trend. The results indicated that the variables in the levels were non-stationary except STR which was stationary in levels under intercept and intercept and trend. However, in the first difference they were all stationary. The order of integration was not greater than one, which is important for long term cointegration analysis. 
Table 2. Lag length selection criteria for cointegration

\begin{tabular}{ccccccc}
\hline Lag & LogL & LR & FPE & AIC & SC & HQ \\
\hline 0 & -633.7625 & NA & 0.009021 & 6.643359 & 6.711223 & 6.670845 \\
1 & 594.0829 & 2391.740 & $2.97 \mathrm{e}-08$ & -5.980030 & $-5.640708^{*}$ & -5.842602 \\
2 & 634.4111 & 76.87575 & $2.31 \mathrm{e}-08^{*}$ & $-6.233449^{*}$ & -5.622669 & $-5.986079^{*}$ \\
3 & 644.4618 & 18.74030 & $2.46 \mathrm{e}-08$ & -6.171477 & -5.289239 & -5.814164 \\
4 & 662.7132 & 33.27069 & $2.40 \mathrm{e}-08$ & -6.194929 & -5.041232 & -5.727673 \\
\hline
\end{tabular}

Prior to apply cointegration analysis, the lag order is determined through the Akaike Information Criterion (AIC) and Schwarz Bayesian Criterion (SBC). Since the study used monthly data, we used with a maximum of four lags. The calculated AIC and SBC figures with different lags were than evaluated. It can be observed from Table 2 that at lag two the AIC criterion is significant. However, the SBC is significant at lag one. In this study we have selected AIC criterion for lag selection.

Table 3. Diagnostic tests for ARDL approach

\begin{tabular}{lccc}
\hline \multicolumn{4}{c}{ Heteroskedasticity Test: Breusch-Pagan-Godfrey } \\
\hline F-statistic & 1.144532 & Prob. F(23,171) & 0.3031 \\
Obs*R-squared & 26.01416 & Prob. CHSQ(23) & 0.3002 \\
\hline \multicolumn{4}{c}{ Breusch-Godfrey Serial Correlation LM Test } \\
\hline Obs*tistic & 0.026587 & Prob. F(2,169) & 0.9738 \\
\hline
\end{tabular}

To test the reliability of the models, a number of diagnostic tests, including tests of serial correlation and Heteroskedasticity in the error term, stability, and accuracy of the model, were applied. We found no evidence of serial correlation in the data. The model Breusch-Pagan-Godfrey test suggesting that the errors are normally distributed and there is no Heteroskedasticity. Hence, it is reasonable to say that the model is well behaved, because the P-values of both tests are greater than .05\% level of significance.

Estimated results of CoIntegration among Stock returns and different economic factors in China using the ARDL approach to cointegration are presented below. We changed dependent variables one by one in the four equations for checking the co-integration. Estimated results of CoIntegration are presented below.

Table 4. Bound tests for cointegration

\begin{tabular}{|c|c|c|}
\hline Dependent variables & F-Statistics & Outcomes \\
\hline F $_{\text {STR }}(\mathrm{STR} / \mathrm{INF}$, INT, EXCR) & 16.82917 & Co-integration \\
\hline F INF $_{\text {INF|STR, INT, EXCR) }}$ & 0.761243 & No-integration \\
\hline F $_{\text {INT }}($ INT|STR, INF, EXCR) & 6.078553 & Co-integration \\
\hline F $_{\text {EXCR }}($ EXCR/STR, INF, INT $)$ & 6.735019 & Co-integration \\
\hline \multicolumn{3}{|c|}{ Critical Bounds Values } \\
\hline Significance & $\mathrm{I}(0)$ Bound & I(1) Bound \\
\hline $10 \%$ & 2.72 & 3.77 \\
\hline $5 \%$ & 3.23 & 4.35 \\
\hline $2.5 \%$ & 3.69 & 4.89 \\
\hline $1 \%$ & 4.29 & 5.61 \\
\hline
\end{tabular}

The above table indicates the results of Co-integration. Our estimated results revealed that co-integration exists in first equation $\mathrm{F}_{\mathrm{STR}}$ (STR|INF, INT, EXCR), because the calculated F-statistics value is greater than the upper bound value of critical bounds values. The second equation $\mathrm{F}_{\mathrm{INF}}$ (INF|STR, INT, EXCR) shows that no co-integration exist in variables when inflation is used as dependent variable because the calculated F-statistics value is less than the lower bound value of critical bounds value. In third equation $\mathrm{F}_{\mathrm{INT}}$ (INT|STR, INF, EXCR) we changed the dependent variable from inflation rate to interest rate and checked the co-integration, our estimated results indicated that co-integration exists among the dependent and independent variables, because the calculated F-statistics value is greater from the upper bound values at $5 \%$ level of significance. The last equation $\mathrm{F}_{\mathrm{EXCR}}$ (EXCR|STR, INF, INT) also confirmed that co-integration exists among dependent and independent variables at 10, 5, 2.5 and $1 \%$ level of significance respectively because the F-statistics value is greater than the upper bound values. 
Table 5. Long run ARDL model

\begin{tabular}{ccccc}
\hline \multicolumn{5}{c}{ Dependent variable Stock Return } \\
\hline Variable & Coefficient & Std. Error & t-Statistic & Prob. \\
\hline EXCHANGE_RATE & 0.005356 & 0.028697 & 0.186631 & 0.8521 \\
INTEREST & -0.023974 & 0.024610 & -0.974155 & 0.3312 \\
INFLATION & 0.000440 & 0.001991 & 0.220828 & 0.8255 \\
C & 0.000086 & 0.394743 & 0.000217 & 0.9998 \\
\hline
\end{tabular}

The above table shows the results of long run ARDL based on Akaike information criterion. Stock return is used as a dependent variable exchange rate, interest rate and inflation rate as independent variables.

Many interesting results emerge from the above estimated model. The estimated coefficient of exchange rate shows positive effect on stock return and statistically non-significant at 5\% level of significance. Exchange rate coefficient indicates that $1 \%$ increase in exchange rate increase stock return up-to $0.53 \%$. Exchange rates have a positive and non-significant effect on stock return which implies that China gain from domestic currency appreciation unlike other countries. Appreciation of home currency can be beneficial for an import orientated sector within each of the countries or for any import oriented country. Also for a country which has both export and import components can gain from appreciation of home currency if the negative effects of currency appreciation on exports is offset by the positive effect of increase in imports due to currency appreciation. Estimated results of exchange rate are consistent with Waqas et al. (2015). Waqas et al. (2015) conducted research on economic factors impact on stock returns in Pakistan, by using secondary data from 1981 to 2013. Their results indicated that exchange rate have positive impact on stock return in Pakistan.

Second, the coefficient of interest rate is negative and statistically non-significant indicating that increase in the interest rate, decrease stock returns in China. Coefficient of interest rate indicates that $1 \%$ increase, decrease stock return up-to $2.39 \%$. Estimated result of interest rate is same with the results of Pilinkus and Boguslauskas (2009). They revealed that unemployment rate, exchange rate, and short-term interest rates negatively influence stock market return. The sign of the interest rates is negative; a one \% increase of interest rates decreases market return by $0.32 \%$.

Coefficient of inflation rate shows positive impact on stock return but statistically non-significant at $5 \%$ level of significance. Inflation's coefficient indicated that one percent increase in inflation rate increase stock return in China $0.04 \%$. Our results are same with Ratanapakorna and Sharma (2007). Ratanapakorna and Sharma (2007) studied the long-term and short-term relationships between the US stock price index, represented by S\&P 500, and macroeconomic variables over the period 1975-1999. Their estimated results indicated that the stock prices are negatively related to the long-term interest rate, but positively related to the money supply, industrial production, inflation, the exchange rate and the short-term interest rate.

Table 6. Short run ARDL model

\begin{tabular}{ccccc}
\hline \multicolumn{5}{c}{ Dependent variable Stock Return } \\
\hline Variable & Coefficient & Std. Error & t-Statistic & Prob. \\
\hline D(EXCHANGE_RATE(-1)) & 0.494452 & 0.216174 & 2.287284 & 0.0233 \\
D(INTEREST) & -0.018580 & 0.019501 & -0.952768 & 0.3419 \\
D(INFLATION) & 0.000341 & 0.001547 & 0.220225 & 0.8259 \\
ECM(-1) & -0.774988 & 0.095108 & -8.148476 & 0.0000 \\
\hline
\end{tabular}

The above table shows the results of short run coefficients of ARDL. Results of short run ARDL shows that the coefficient of exchange rate have positive and statistically significant impact on stock return in China in short run. Coefficient of exchange rate indicates that $1 \%$ increase in exchange rate increase stock return up-to $49.44 \%$ in China. Exchange rate is statistically significant at 5\% level of significance. Interest rate coefficient shows negative and statistically non-significant impact on stock return in China. Coefficient of interest rate indicates that when interest rate increases 1\% it negatively impact on stock return and stock return decrease up-to $1.858 \%$ in China. Inflation rate coefficient indicates that inflation rate have positive and statistically non-significant impact on stock return. Coefficient of inflation shows that $1 \%$ increase have positive impact on stock return in China and increase stock return up-to $0.03 \%$.

The error correction model was examined to evaluate the short run dynamic relationship between stock returns and its external determinants (Inflation, Interest and Exchange rate), and to confirm the reliability of the long 
term coefficient. It was estimated by normalizing the long run estimates. The different components in the ARDL equation were substituted with the ECM item. Table 6 shows the ECM results In Panel (A) the estimated ECM indicate that the ECM coefficient carries an inverse sign and is statistically significant at the one percent level which is preferable. Thus, the short run model was consistent. The estimated ECM coefficient (- 0.7749) also determines the speed (0.7749) of the correction towards an equilibrium relationship. Further, the ECM also indicates that any divergence from the long run relation in the current period should be adjusted by around 77 percent in the following period implying that adjustment is acceptable.

Table 7. Diagnostics test

\begin{tabular}{lclc}
\hline R-squared & 0.9991 & AIC & -4.3812 \\
\hline Adjusted R-squared & 0.9990 & SIC & -4.2168 \\
F-statistic & 669.4427 & Durbin-Watson stat & 2.0120 \\
Prob (F-statistic) & 0.0000 & & \\
\hline
\end{tabular}

Table 7 shows the results of diagnostics test. Calculated R-squared value shows that $99 \%$ variation in stock returns in China is explained by interest rate, inflation rate and exchange rate. AIC and SIC value are respectively -4.3812 and -4.2168 which indicates that the model is statistically fit and suitable for our data. Durbin Watson statistics value shows that there is no problem of autocorrelation problem in our data. The reliability check in the above table is validated that the calculated ECM equation did not have serious estimation issues.

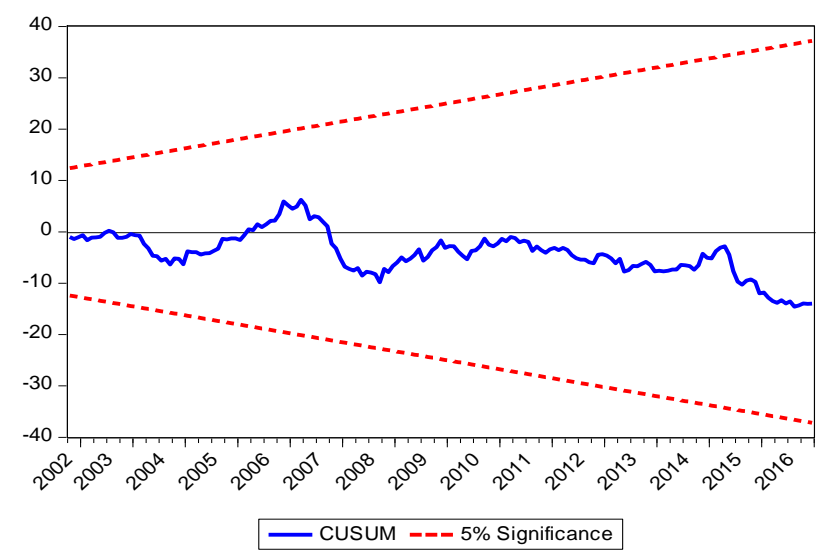

Figure 1. Plot of cumulative sum of the recursive residuals (CUSUM)

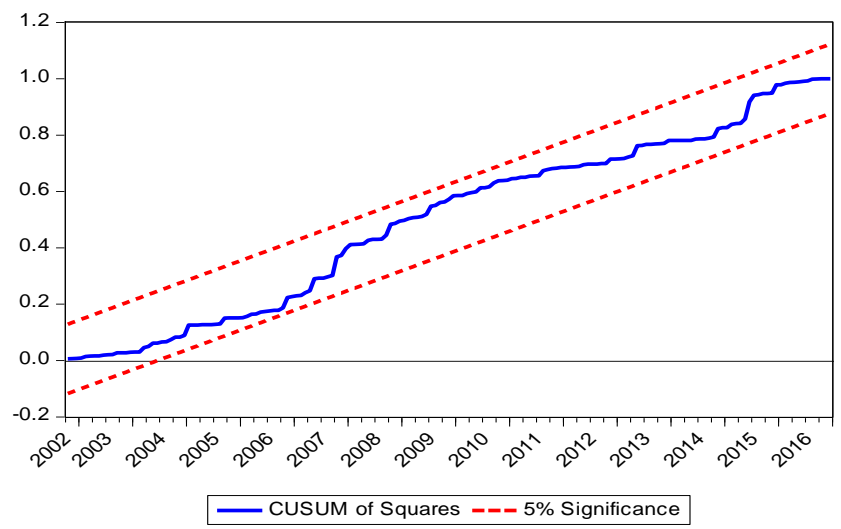

Figure 2. Plot of cumulative sum of squares of recursive residual (CUSUMSQ)

Finally, the stability of the estimates were assessed by employing the cumulative sum (CUSUM) of the recursive residuals and the cumulative sum of squares (CUSUMSQ) of the recursive residual test. Figures 1 and 2 provide plots of these tests, respectively. Figures 1 and 2 indicate that the CUSUM and CUSUMSQ test statistics, respectively, could not exceed the critical limits at the five percent significance level. Therefore, the regression models appeared to be stable. 


\section{Conclusions and Recommendations}

In this study, we have applied autoregressive distributed lag model (ARDL) for examining the effect of economic factors on the stock returns of Shanghai stock exchange, China. The results obtained suggest that stock returns fluctuations over the long-term in China are strongly related to the level of economic factors fluctuations in China. Results of short and long run ARDL indicates that exchange rate and inflation rate have positive effect on stock returns while interest rate have negative effect on stock returns in Shanghai stock exchange. Based on the empirical test results, the investors of Shanghai stock exchange should pay attention to both the domestic and international macroeconomic developments. Developments in China industrial production index, consumer price index, real exchange rate and the domestic stock prices/returns in short and long-run. In future research can enhance the scope of this study by including the other stock exchange in China with other economic factors.

\section{Acknowledgements}

We would like to thank Gao Wei and Guo Jian-Hua for their constructive and valuable comments and suggestions. Authors are also grateful to Xiao Li from Jilin University for their helpful comments. Prof. Jian-Zhou Teng acknowledges financial support from China's national Social Science research grant (16BTJ025).

\section{References}

Abdalla, I. S., \& Murinde, V. (1997). Exchange rate and stock price interactions in emerging financial markets:evidence on India, Korea, Pakistan and the Philippines. Applied Financial Economics, 7(1), 25-35. https://doi.org/10.1080/096031097333826

Adom, P. K., Bekoe, W., \& Akoena, S. K. K. (2012). Modelling aggregate domestic electricity demand in Ghana: An autoregressive distributed lag bounds cointegration approach. Energy Policy, 42, 530-537. https://doi.org/10.1016/j.enpol.2011.12.019

Alagidede, P., \& Panagiotidis, T. (2010). Can common stocks provide a hedge against inflation? Evidence from African countries. Review of Financial Economics, 19(3), 91-100. https://doi.org/10.1016/j.rfe.2010.04.002

Bornholt, G. (2013). The failure of the Capital Asset Pricing Model (CAPM): An update and discussion. Abacus, 49(S1), 36-43. https://doi.org/10.1111/j.1467-6281.2012.00382.x

Brooks, C. (2014). Introductory econometrics for finance. Cambridge university press.

Brown, R. L., Durbin, J., \& Evans, J. M. (1975). Techniques for testing the constancy of regression relationships over time. Journal of the Royal Statistical Society, Series B (Methodological), 149-192. Retrieved from http://www.jstor.org/stable/2984889

Chen, N. F., Roll, R., \& Ross, S. A. (1986). Economic forces and the stock market. Journal of Business, 383-403. https://doi.org/10.1086/296344

Choi, J. J. (1995). The Japanese and US stock prices: A comparative fundamental analysis. Japan and the World Economy, 7(3), 347-360. https://doi.org/10.1016/0922-1425(95)00010-5

Dempsey, M. (2013). The capital asset pricing model (CAPM): the history of a failed revolutionary idea in finance?. Abacus, 49(S1), 7-23. https://doi.org/10.1111/j.1467-6281.2012.00379.x

Duasa, J. (2007). Determinants of Malaysian trade balance: An ARDL bound testing approach. Global Economic Review, 36(1), 89-102. http://dx.doi.org/10.1080/12265080701217405

Eita, J. H. (2012). Inflation and stock market returns in South Africa. The International Business \& Economics Research Journal (Online), 11(6), 677. https://doi.org/10.19030/iber.v11i6.7020

Engle, R. F., \& Granger, C. W. (1987). Co-integration and error correction: Representation, estimation, and testing. Econometrica: Journal of the Econometric Society, 251-276. https://doi.org/10.2307/1913236

Fama, E. F. (1981). Stock returns, real activity, inflation, and money. The American Economic Review, 71(4), 545-565. Retrieved from http://www.jstor.org/stable/1806180

Fama, E. F. (1990). Stock returns, expected returns, and real activity. The Journal of Finance, 45(4), 1089-1108. https://doi.org/10.1111/j.1540-6261.1990.tb02428.x

Gallinger, G. W. (1994). Causality tests of the real stock return-real activity hypothesis. Journal of Financial Research, 17(2), 271-288. https://doi.org/10.1111/j.1475-6803.1994.tb00191.x

Gujarati, D. N. (2009). Basic econometrics. Tata McGraw-Hill Education.

Johansen, S. (1991). Estimation and hypothesis testing of cointegration vectors in Gaussian vector autoregressive 
models. Econometrica: Journal of the Econometric Society, 1551-1580. https://doi.org/10.2307/2938278

Kanas, A., \& Karkalakos, S. (2017). Equity flows, stock returns and exchange rates. International Journal of Finance \& Economics, 22(2), 159-168. https://doi.org/10.1002/ijfe.1574

Kaur, D., \& Sahu, N. G. (2009). Correlation and causality between stock market and macro economic variables in India: An empirical study (Doctoral dissertation).

Khalid, M. (2012). Long-run Relationship between Macroeconomic Variables and Stock Return: Evidence from Karachi Stock Exchange (KSE). School of Doctoral Studies European Union, 95.

Khumalo, J. (2013). Inflation and stock prices interactions in South Africa: VAR analysis. International Journal of Economics and Finance Studies, 5(2), 23-34.

Kuwornu, J. K. (2012). Effect of macroeconomic variables on the ghanaian stock market returns: A co-integration analysis. Agris on-line Papers in Economics and Informatics, 4(2), 15.

Kwon, C. S., \& Shin, T. S. (1999). Cointegration and causality between macroeconomic variables and stock market returns. Global Finance Journal, 10(1), 71-81. https://doi.org/10.1016/S1044-0283(99)00006-X

Marx, C., \& Struweg, J. (2015). Stagflation and the South African equity market. Procedia Economics and Finance, 30, 531-542. https://doi.org/10.1016/S2212-5671(15)01265-4

Menike, L. M. C. S. (2010). The effect of macroeconomic variables on stock prices in emerging Sri Lankan stock market. Sabaragamuwa University Journal, 6(1). https://doi.org/10.4038/suslj.v6i1.1689

Mukherjee, T. K., \& Naka, A. (1995). Dynamic relations between macroeconomic variables and the Japanese stock market: An application of a vector error correction model. Journal of Financial Research, 18(2), 223-237. https://doi.org/10.1111/j.1475-6803.1995.tb00563.x

Pesaran, M. H., \& Shin, Y. (1999). An autoregressive distributed-lag modelling approach to cointegration analysis. Econometric Society Monographs, 31, 371-413. https://doi.org/10.1017/CCOL521633230.011

Pesaran, M. H., Shin, Y., \& Smith, R. J. (2001). Bounds testing approaches to the analysis of level relationships. Journal of Applied Econometrics, 16(3), 289-326. https://doi.org/10.1002/jae.616

Phiri, A. (2017). Long-run equilibrium adjustment between inflation and stock market returns in South Africa: A nonlinear perspective. International Journal of Sustainable Economy, 9(1), 19-33. https://doi.org/10.1504/IJSE.2017.080866

Pilinkus, D., \& Boguslauskas, V. (2009). The short-run relationship between stock market prices and macroeconomic variables in Lithuania: An application of the impulse response function. Engineering Economics, 65(5).

Ratanapakorn, O., \& Sharma, S. C. (2007). Dynamic analysis between the US stock returns and the $\begin{array}{lllll}\text { macroeconomic variables. Applied Financial } & \text { Economics, } & \text { 17(5), } & \text { 369-377. }\end{array}$ http://dx.doi.org/10.1080/09603100600638944

Rjoub, H., Türsoy, T., \& Günsel, N. (2009). The effects of macroeconomic factors on stock returns: Istanbul Stock Market. Studies in Economics and Finance, 26(1), 36-45. https://doi.org/10.1108/10867370910946315

Singh, T., Mehta, S., \& Varsha, M. S. (2011). Macroeconomic factors and stock returns: Evidence from Taiwan. Journal of Economics and International Finance, 3(4), 217.

Sukruoglu, D., \& Nalin, H. T. (2014). The macroeconomic determinants of stock market development in selected European countries: Dynamic panel data analysis. International Journal of Economics and Finance, 6(3), 64. http://dx.doi.org/10.5539/ijef.v6n3p64

Waqas, Y., Hashmi, S. H., \& Nazir, M. I. (2015). Macroeconomic factors and foreign portfolio investment volatility: A case of South Asian countries. Future Business Journal, 1(1), 65-74. https://doi.org/10.1016/j.fbj.2015.11.002

\section{Copyrights}

Copyright for this article is retained by the author(s), with first publication rights granted to the journal.

This is an open-access article distributed under the terms and conditions of the Creative Commons Attribution license (http://creativecommons.org/licenses/by/4.0/). 